\title{
Working
}

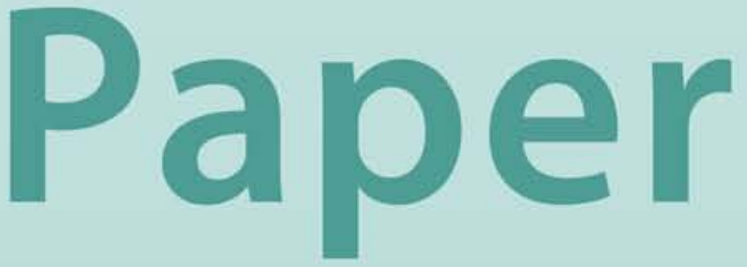


Modeling Inflation in Chad

Tidiane Kinda 


\title{
IMF Working Paper
}

\author{
African Department
}

\section{Modeling Inflation in Chad}

Prepared by Tidiane Kinda ${ }^{1}$

Authorized for distribution by Mauro Mecagni

March 2011

\begin{abstract}
This Working Paper should not be reported as representing the views of the IMF. The views expressed in this Working Paper are those of the author(s) and do not necessarily represent those of the IMF or IMF policy. Working Papers describe research in progress by the author(s) and are published to elicit comments and to further debate.

This paper examines the determinants of inflation in Chad using quarterly data from 1983:Q1 to 2009:Q3. The analysis is based on a single-equation model, completed by a structural vector auto regression model to capture inflation persistence. The results show that the main determinants of inflation in Chad are rainfall, foreign prices, exchange rate movements, and public spending. The effects of rainfall shocks and changes in foreign prices on inflation persist during six quarters. Changes in public spending and the nominal exchange rate affect inflation during three and four quarters, respectively.

JEL Classification Numbers:C22, C32, E31, E62.

Keywords: Inflation, Rainfall, External shocks, Public spending, Cointegration, Singleequation model, Structural VAR.

Author's E-Mail Address: tkinda@imf.org

\footnotetext{
${ }^{1}$ The paper has benefited from comments and suggestions by officials during a seminar in Chad as part of the 2010 Article IV consultation and participants at the $15^{\text {th }}$ African Econometric Conference in Cairo, as well as Charles Amo-Yartey, Christian Josz, Joseph Karangwa, Shawn Ladd, Mauro Mecagni, Seán Nolan, and Jaroslaw Wieczorek. The author is also grateful for editorial comments from Jenny Di Biase and Diane Ullius.
} 
Contents

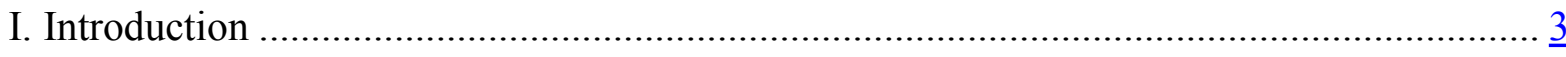

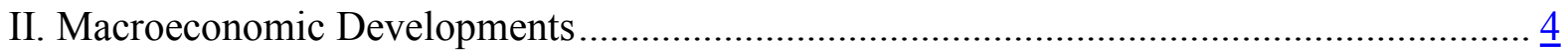

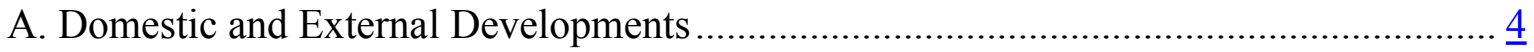

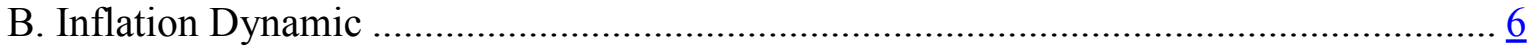

III. The Theoretical Framework................................................................................ 7

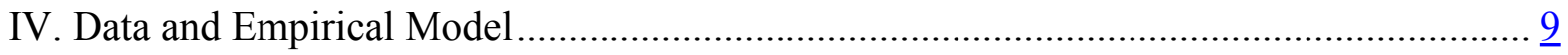

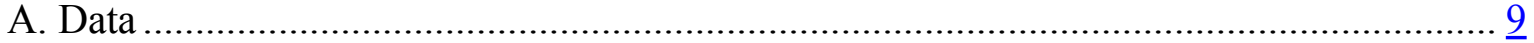

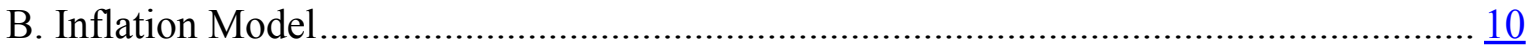

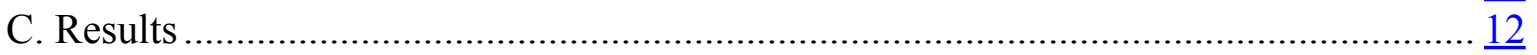

D. Structural Vector Autoregression Model ........................................................ 15

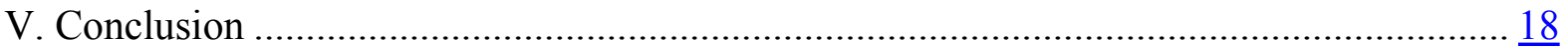

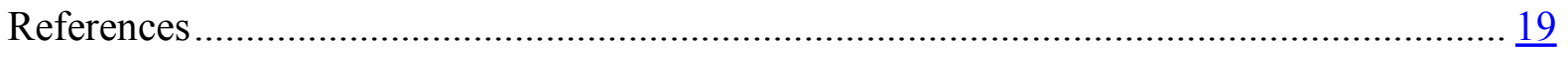

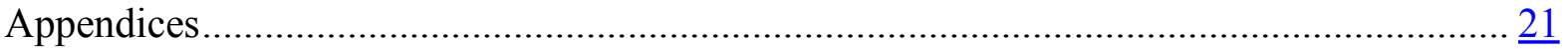

Tables

Table 1. Chad: Long-Run Equilibrium in the Money Market ......................................... 11

Table 2. Chad: Long-Run Equilibrium in the External Market ....................................... 11

Table 3. Chad: Inflation Model.............................................................................. 15

Table A.1. Chad: Weights of the Components/Subcomponents of the CPI ........................ $\frac{12}{22}$

Table A.2. Chad: Definitions and Sources of Variables ................................................ $\frac{22}{23}$

Table A.3. Chad: Unit Root Test .............................................................................. $\frac{23}{26}$

Table A.4. Chad: Johansen Cointegration Test, Money Market Equilibrium ...................... 26

Table A.5. Chad: Johansen Cointegration Test, External Market Equilibrium .................... 26

Table A.6. Chad: Diagnostic Statistics for the Single-Equation Inflation Models ................. $\underline{30}$

Figures

Figure 1. Chad: Domestic and External Developments, 2002-09 …................................ $\underline{5}$

Figure 2. Chad: Annual Inflation (percent), 1983-2009............................................ 7

Figure 3. Chad: Monthly Consumer and Food Price Indexes, 2005:M12-2010:M3 ............. $\frac{7}{7}$

Figure 4. Chad: Impulse Response of Inflation ........................................................ $\frac{17}{24}$

Figure A.1. Chad: Evolution of the Main Variables .................................................... $\frac{24}{25}$

Figure A.2. Chad: Four-Quarter Lag Moving Average of the National Rainfall and CPI .... 25

Figure A.3. Chad: Actual and Predicted Quarterly Inflation (Specification 1) ................... 27

Figure A.4. Chad: Residuals (Specification 1) .......................................................... 27

Figure A.5. Chad: Actual and Predicted Quarterly Inflation (Specification 2) ................... $\frac{28}{28}$

Figure A.6. Chad: Residuals (Specification 2) ........................................................ 28

Figure A.7. Chad: Actual and Predicted Quarterly Inflation (Specification 3) ................... $\underline{29}$

Figure A.8. Chad: Residuals (Specification 3) ............................................................ 29 


\section{INTRODUCTION}

Inflation in Chad reached 8-10 percent over 2008 and 2009, while it averaged 31/2 percent in neighboring members of the Central African Economic and Monetary Community (CEMAC). Reducing this gap is important if Chad is to comply with the CEMAC inflation convergence criterion of 3 percent or less. Reducing inflation, in particular food-price inflation, is also critical to protecting the purchasing power of the poor. Therefore, understanding the main drivers of inflation is fundamental to ensuring macroeconomic stability and fighting poverty in Chad.

This paper provides the first empirical analysis of inflation determinants focusing on Chad. Using quarterly data from 1983:Q1 to 2009:Q3, the analysis is based on monetary and external theories of inflation. Supply-side constraints, captured by agricultural shocks, and institutional factors, captured by episodes of political instability, are also accounted for. In addition, the analysis includes major historical events such as the devaluation of the CFAF in 1994 and the start of oil production in 2003.

Several previous studies of inflation and its determinants in Sub-Saharan African countries suggest directions for analysis of Chad. Diouf (2007) analyzed the inflation dynamics in Mali. Like Chad, Mali is a low-income landlocked country and a member of a monetary union similar to the CEMAC. Diouf (2007) found that average national rainfall and monetary and external factors explain inflation. In Ethiopia, Loening, Durevall, and Birru (2009) found that agricultural shocks, exchange rate, and foreign prices affect inflation. In the case of Sudan, an oil-producing country, Moriyama (2008) shows that changes in money supply and nominal exchange rate affect inflation with 18- to 24-month time lags. Klein and Kyei (2009) and Kandil and Morsy (2009) analyzed inflation in other oil-producing countries, such as Angola and the Gulf Cooperation Council (GCC) countries. Klein and Kyei (2009) found that exchange rate movements and excess liquidity drive inflation in Angola. For the GCC countries, Kandil and Morsy (2009) concluded that inflation in trading partners as well as credit and aggregate spending explain inflation. Coleman (2010) analyzed inflation persistence in 13 Communauté Financière Africaine (CFA) member states and highlighted that inflation is persistent in Chad, Cote d'Ivoire, and Niger. ${ }^{2}$

The empirical strategy in this paper combines three estimation methods: the vector error correction model (VECM), the single-equation model, and the structural vector auto regression (SVAR). The single-equation model, augmented with error correction terms from the VECM, shows that supply-side constraints, public spending, and external factors are the

\footnotetext{
${ }^{2}$ Recent analyses of inflation determinants also include Barnichon and Peiris (2008) for sub-Saharan Africa as a whole, Ubide (1997) for Mozambique, Blavy (2004) for Guinea, Nassar (2005) for Madagascar, and Gottschalk, Kalonji, and Miyajima (2008) for Sierra Leone.
} 
main drivers of inflation in Chad. Rainfall affects domestic prices with a three-quarter lag, through its impact on agricultural production. Public spending has a significant impact on inflation (with a one-quarter lag) through demand pressures on nontradables. Changes in trading partner prices and exchange rate movements are passed through imports to domestic prices, one quarter later.

The SVAR model also points to rainfall, foreign prices, exchange rate, and public spending as the main determinants of inflation. It also shows some persistent effects. For instance, while the impact of rainfall shock on inflation is at its highest three quarters after the shock, this impact persists until the sixth quarter. The dynamics are the same for foreign prices, the exchange rate, and public spending; the effect on inflation persists for three to six quarters.

In what follows, Section II presents recent developments in different sectors of the Chadian economy and analyzes inflation dynamics. Section III presents a simple theoretical framework to analyze inflation determinants. Section IV presents the data, discusses the empirical models, and interprets the results. The last section draws conclusions.

\section{MACROECONOMiC DEVELOPMENTS}

\section{A. Domestic and External Developments}

Since 2003, oil production has offered a unique opportunity for Chad to achieve sustained growth and reduce poverty. Over the past decade, Chad's macroeconomic outlook has been transformed by oil exploitation and related activities through their impact on public finances and the real economy (Figure 1).

Oil production has dramatically improved government revenue, funding a surge in public expenditure. Public expenditure as a share of non-oil GDP has doubled since 2003, reaching 46 percent in 2009. As a result, the non-oil primary balance reached 28 percent of non-oil GDP in 2009, well above its estimated long-term sustainable level (which is in the low single digits). Thanks to higher revenue from oil exports, the current account balance has also improved by more than 50 percent of the GDP between 2002 and 2009.

Despite the start of oil production, the monetization of the economy remains low, and credit to the private sector limited. The fragile security situation remains a major obstacle for private sector growth, jeopardizing the development of a business-friendly environment that would promote a competitive private sector.

The real exchange rate has appreciated over 2008 and 2009. In addition to the appreciation of the euro against the dollar between 2008 and 2009, which has been partly reversed so far in 2010, inflation in Chad has been higher than in its trading partners, fueling real appreciation and reducing competitiveness. 
After a surge at the beginning of the oil era, real growth has been disappointing since 2005 . Since 2005, growth performance has been poor mainly because of the decreasing trend in oil production. In 2009, real GDP contracted by 1.6 percent because of the contraction in the oil sector and the collapse of agricultural production owing to poor rainfall.

Figure 1. Chad: Domestic and External Developments, 2002-09
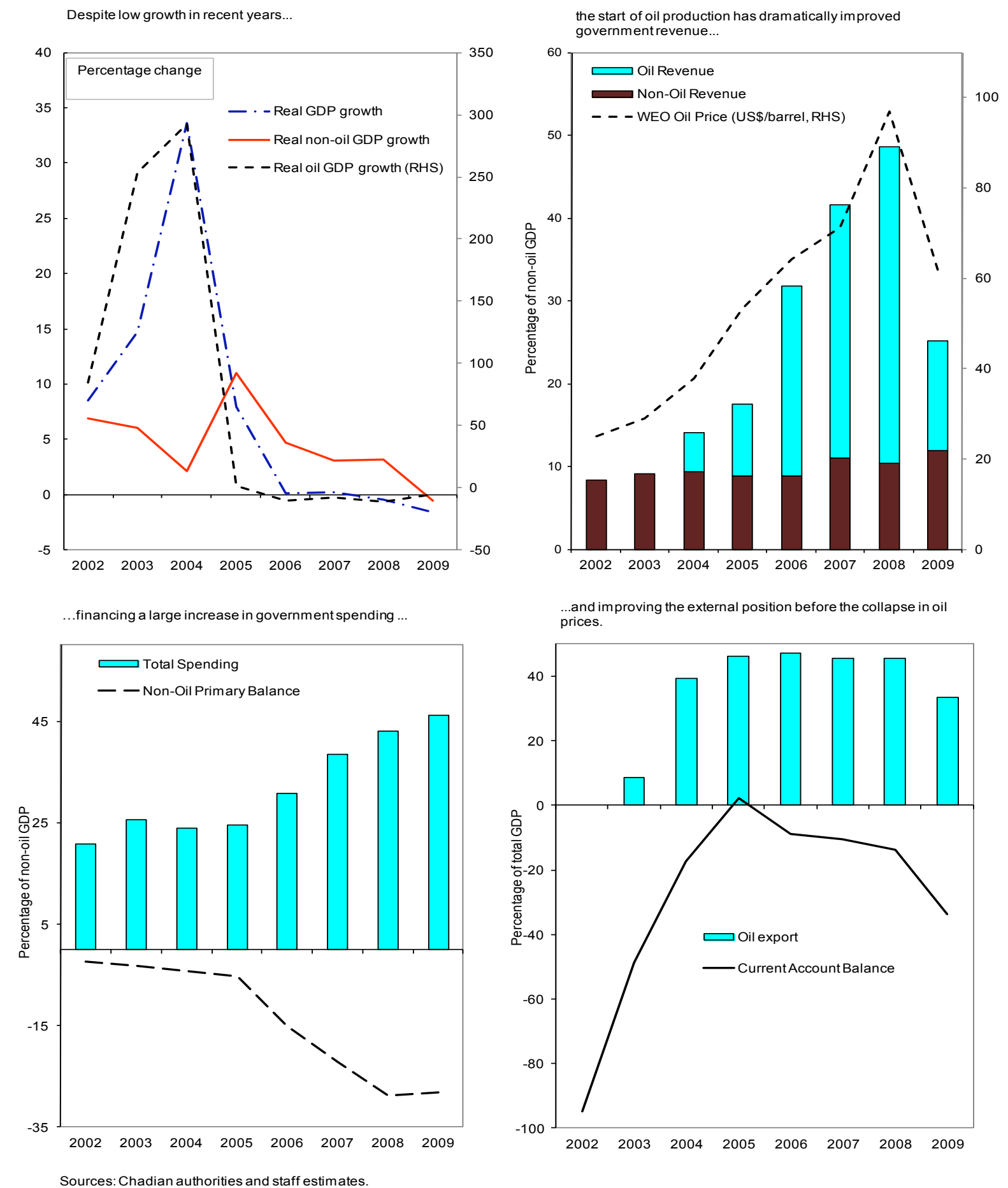
Figure 1. Chad: Domestic and External Developments, 2002-09 [concluded]

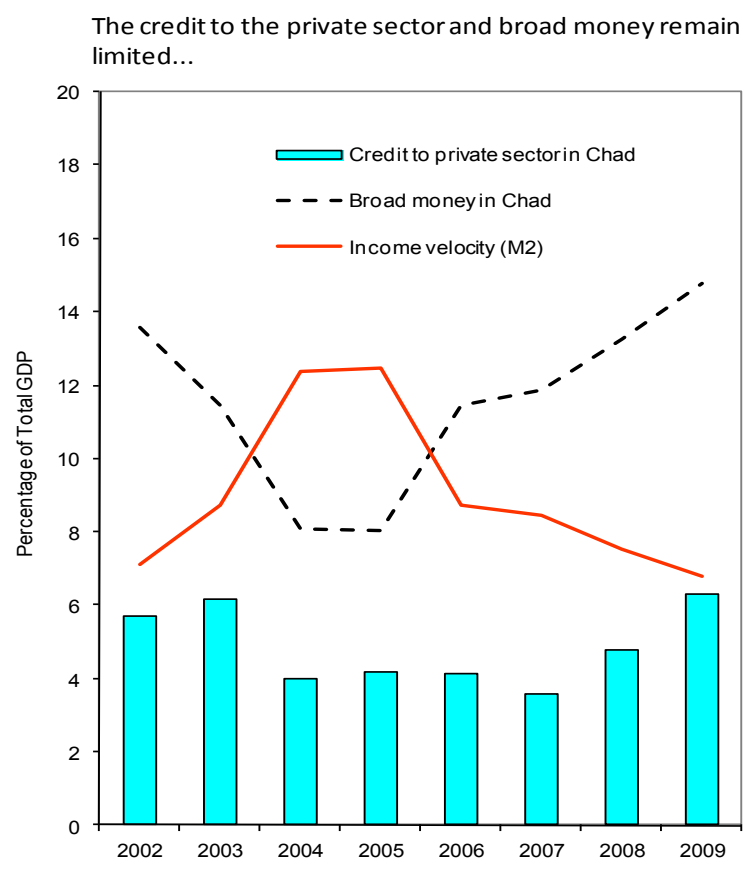

....and the real exchange rate slightly appreciated during recent years.

Sources: Chadian authorities and staff estimates.

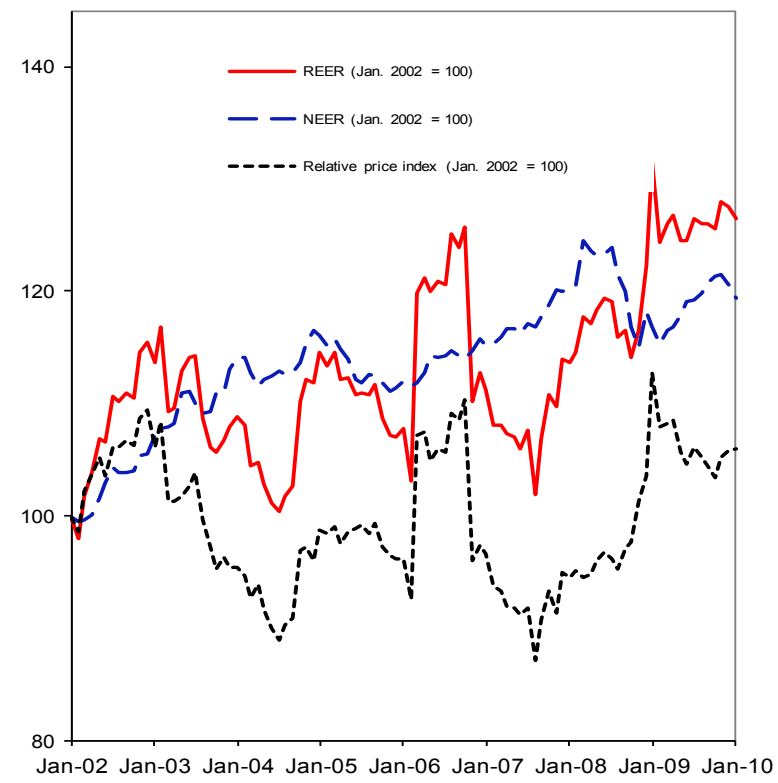

\section{B. Inflation Dynamics}

Inflation $^{3}$ in Chad has historically been moderate, averaging 4.5 percent from 1983 to 2009, although with sizeable year-to-year fluctuations. It has moderated since 2000, averaging 3.8 percent, but is still subject to significant shocks. Figure 2 illustrates the inflation dynamics with the devaluation of the CFAF by 50 percent in January 1994 as the major event. Indeed, after the devaluation, inflation surged from minus 8 percent in 1993 to plus 42 percent in 1994. Other events such as the floods in 1999 and 2007 and drought in 2001 were also associated with large increases in inflation.

\footnotetext{
${ }^{3}$ The consumer price index (CPI), which covers only N'Djamena, the capital city, includes 332 products. Its weights are based on a survey that covered 1,024 households in N'Djamena in 2003-04 (ECOSIT2). Table A.1 presents the distribution of the weights across the main categories of products covered. At 46 percent of the index, food and nonalcoholic beverages dominate the CPI.
} 
Figure 2. Chad: Annual Inflation (percent), 1983-2009

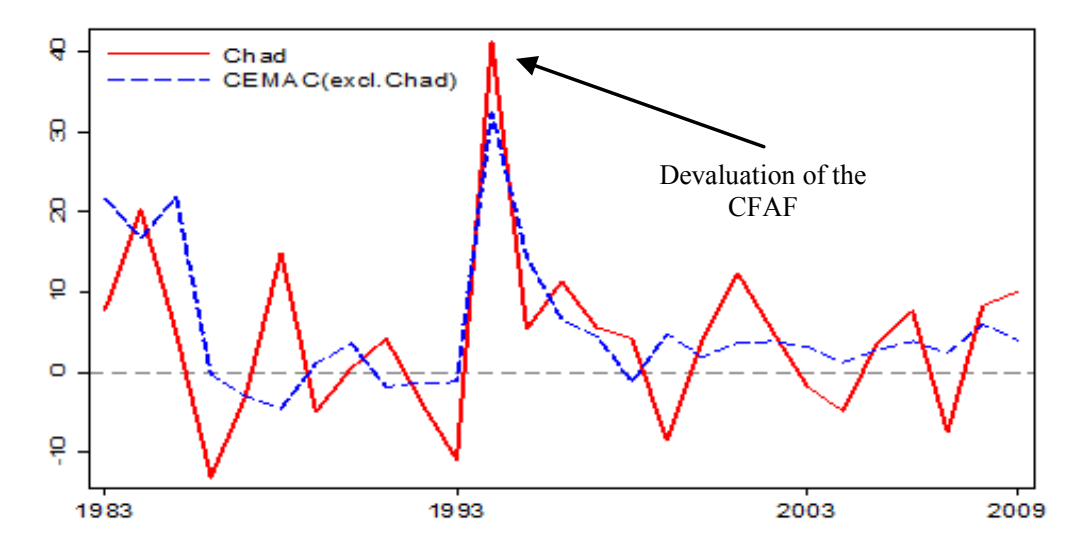

In recent years, a significant rise in food prices, concomitant with the global food crisis of 2008, chiefly explains inflation developments (Figure 3). ${ }^{4}$

Figure 3. Chad: Monthly Consumer and Food Price Indexes, 2005:M12-2010:M3

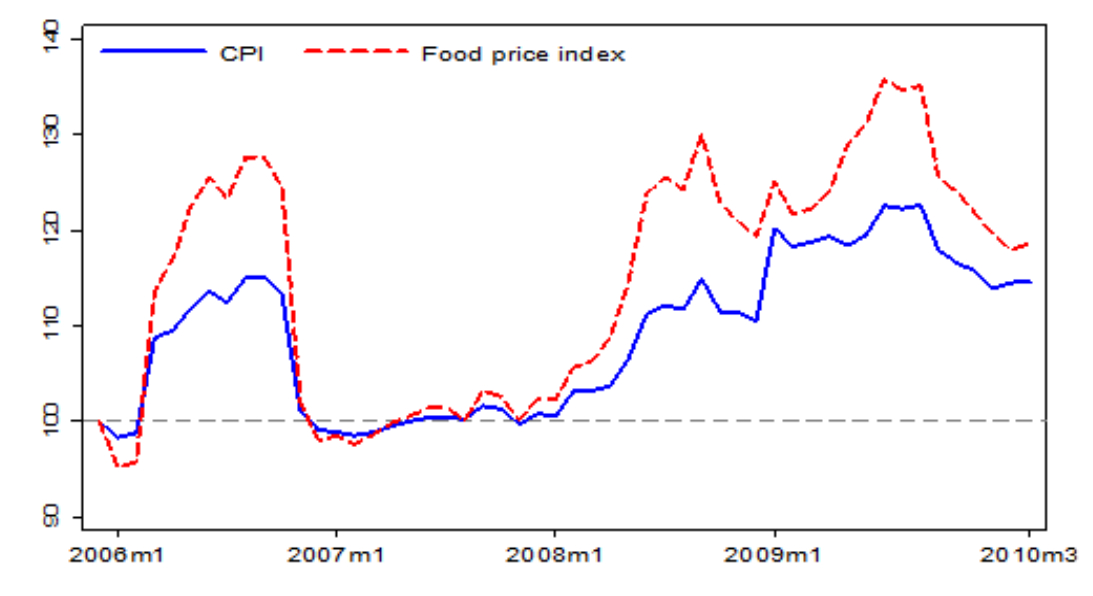

\section{The Theoretical FrameWork}

This section describes a simple theoretical framework that could be used to explain inflation in Chad. Following Ubide (1997), three theories could explain Chad's inflation behavior: (i) the external sector theory; (ii) the monetary theory; and (iii) the markup theory.

Two of these theories (external sector and monetary) are pertinent to Chad. The third (markup) relies on domestic labor market disequilibrium that is difficult to measure in Chad. Only 9 percent of workers are paid employees in Chad; the majority (63 percent) are selfemployed in agriculture (Montenegro and Maximilian, 2009). Therefore, most households in

\footnotetext{
${ }^{4}$ Components and subcomponents of the CPI have been available since December 2005.
} 
Chad obtain their income from nonwage activities. In addition, wage data are of poor quality. ${ }^{5}$

Applying an IS-LM framework to a small open economy, the general price level is a weighted average of tradable prices $\left(p_{t}^{T}\right)$ and nontradables prices $\left(p_{t}^{N T}\right)$ :

$$
p_{t}=\delta p_{t}^{T}+(1-\delta) p_{t}^{N T}
$$

where all variables are expressed in natural logarithms, and $0<\delta<1$ represents the share of tradable goods in the total consumption basket. Assuming purchasing power parity (PPP), the price of tradables $\left(p_{t}^{T}\right)$, which is internationally determined, is a function of foreign prices $\left(p_{t}^{*}\right)$ and the exchange rate $\left(e_{t}\right)$.

$$
p_{t}^{T}=p_{t}^{*}+e_{t}
$$

Assuming that demand for nontradables follows aggregate demand in the economy, the price of nontradables is determined by the equilibrium in the money market:

$$
\left(m_{t}-p_{t}\right)=\left(m_{t}^{d}-p_{t}\right)
$$

where $\left(m_{t}-p_{t}\right)$ is the real money supply and $\left(m_{t}^{d}-p_{t}\right)$ the real money demand. $m_{t}$ represents broad money, and $p_{t}$, the price level measured by the CPI. Representing the relationship between aggregate demand and the demand for nontradable goods by $\varphi$, the price of nontradables is as follows:

$$
p_{t}^{N T}=\varphi\left(m_{t}-\left(m_{t}^{d}-p_{t}\right)\right)
$$

Real money demand can be modeled as a function of real income $\left(y_{t}-p_{t}\right)$, inflation expectations $(E(\pi))$, and the rate of return $\left(r_{t}\right)$, which is measured by the difference between the Bank of Central African States (BEAC) discount rate and the annual time deposit interest rate captures the opportunity cost of substitution between assets and money:

$$
m_{t}^{d}-p_{t}=\alpha+\beta\left(y_{t}-p_{t}\right)+\rho r_{t}+\mu E(\pi)
$$

Assuming for simplicity that inflation expectations depend only on past inflation and the realization of past inflation forecasts $\left(E(\pi)=\Delta p_{t-1}\right)$ substituting Equation 5 in Equation 4 yields Equation 6:

\footnotetext{
${ }^{5}$ Diouf (2007) also concluded that modeling the domestic labor market to explain inflation in Mali was not relevant. Chibber and Shafik (1990) found that wage increases rarely cause inflation in Africa.
} 


$$
p_{t}^{N T}=\varphi\left(m_{t}-\left(\alpha+\beta\left(y_{t}-p_{t}\right)+\rho r_{t}+\mu \Delta p_{t-1}\right)\right)
$$

A priori, we expect $\beta$ to be positive, as higher real income increases money demand for transactions. $\rho$ is expected to be negative because a higher return on assets makes them more attractive than money. Substituting Equation 6 and Equation 2 in Equation 1yields a reduced form equation that can be estimated:

$$
p_{t}=f\left(e_{t}, p_{t}^{*}, m_{t}, y_{t}-p_{t}, r_{t}, \Delta p_{t-1}\right)
$$

A depreciation of the exchange rate is expected to fuel inflation by increasing import prices. Higher prices in trading partners, money supply, and real income are also expected to increase inflation. A higher rate of return is expected to be associated with a decrease in money holding, reducing inflation. The effect of past inflation on the current price level is undetermined. On the one hand, higher inflation expectation, resulting from higher inflation in the previous period, could reduce money demand and consequently increase prices. On the other hand, inflation could persist because of sluggish adjustment owing to rigidities and structural constraints, such as those associated with poor infrastructure.

The derived empirical model is augmented to include structural factors specific to Chad, such as agricultural production shocks (captured by national rainfall), periods of political instability (rebel assaults or major social tensions), as well as major events like the devaluation of the CFAF, and the start of oil production.

\section{DATA ANd EMPIRICAL MODEL}

\section{A. Data}

The study uses quarterly data from 1983:Q1 to 2009:Q3. Quarterly real GDP and quarterly government expenditures are interpolated from annual data using the proportional Denton method (see Bloem, Dippelsman, and Maehle, 2001). Quarterly rainfall data are averages of monthly rainfall data from the Chad Meteorological Office (DREM) for 2000-08. These data are completed with annual rainfall data from the Food and Agriculture Organization for 1983-1999 (Miguel, Satyanath, and Sergenti, 2004). Quarterly rainfall data for 19831999 are derived from annual data by applying the seasonal pattern observed from 2000 through 2008 . The quarterly political instability variable, which measures rebel assaults, is constructed with information from a variety of sources. Table A.2 summarizes the definitions and sources of variables.

Table A.3 illustrates the statistical properties of the data. Augmented Dickey-Fuller and Phillips-Perron tests reveal that all variables are nonstationary in level but stationary in first difference. Figure A.1 illustrates the evolution of the main variables, and Figure A.2 plots the moving average of lagged national rainfall and the CPI. 


\section{B. Inflation Model}

Estimating a single-equation model reduces the risk of a heavily parameterized vector auto regression (VAR) model. VAR models of inflation could be estimated or vector error correction models when cointegrating vectors are present. However, because of the small number of observations in this study, we follow an approach widely used to help interpret the interactions between short-run and long-run variables (Juselius, 1992; Diouf, 2007). The approach consists in first estimating the long-run equilibrium in each market (money market and external market) using sectoral VECMs. The deviations from the long-run equilibrium (the error correction terms) are then integrated into a short-run model to specifiy a singleequation inflation model.

\section{Long-run equilibrium in the money and external markets}

\section{The long-run money market equilibrium}

The long-run money market equilibrium is estimated from Equation 5. Because all variables contain a unit root and are stationary in first difference, $\Delta p_{t-1}$ is stationary and cannot be included in a long-run relationship. However, $\Delta p_{t-1}$ could directly integrate the short-run inflation model. The Johansen cointegration test does not reject the null hypothesis of one cointegrating vector (Table A.4). Therefore, there could be one cointegrating vector that explains the long-run equilibrium in the money market.

The long-run equilibrium in the money market is estimated with a vector error correction model. As expected, the results show that real income positively explains money demand (Table 1). Higher real income induces higher demand for money. A higher rate of return on assets, captured by the difference between the BEAC discount rate and the time deposit rate, reduces broad money, but the error correction term is fairly significant in this equation (column 2). ${ }^{6}$

The error correction term ( $\left.e c_{\text {money }}\right)$, representing the long-run disequilibrium in the money market (Table 1, column 1) that will be included in the inflation model is as follows:

$$
\begin{gathered}
e c_{\text {money }}=\left(m_{t}-p_{t}\right)-\alpha-\beta\left(y_{t}-p_{t}\right)-\rho r_{t} \\
e c_{\text {money }}=\left(m_{t}-p_{t}\right)-3.39\left(y_{t}-p_{t}\right)
\end{gathered}
$$

\footnotetext{
${ }^{6}$ The central bank discount rate is preferred in estimating the return rate for assets because of its better availability. However, the shallow financial system could limit the impact of the discount rate on broad money.
} 
Table 1. Chad: Long-Run Equilibrium in the Money Market

\begin{tabular}{lcc}
\hline \multicolumn{3}{c}{ Dependent variable: $\log ($ Real broad money) } \\
\hline Log(Real GDP) & $3.39^{*}$ & $(2)$ \\
& $(1.83)$ & $5.13^{* *}$ \\
Discount minus deposit rate & & $(2.23)$ \\
& & $-0.49 * * *$ \\
Error Correction & $-0.10^{* * *}$ & $(-3.93)$ \\
& $(-2.41)$ & -0.05 \\
& 114 & $(-1.52)$ \\
\hline Observations & 114 \\
Numbers in parentheses are t-statistics. & \\
*significant at $10 \%, * *$ significant at $5 \%, * *$ significant at $1 \%$ &
\end{tabular}

\section{The long-run external market equilibrium}

Chad's long-run external market equilibrium is estimated from Equation 2, (a PPP relationship), without distinction between tradable and nontradable goods prices. Johansen cointegration tests indicate that a single cointegrating vector could explain the long-run external market equilibrium (Table A.5), which allows us to estimate it with a VECM. As expected, higher prices in Chad's trade partners increase domestic inflation (Table 2).

Table 2. Chad: Long-Run Equilibrium in the External Market

\begin{tabular}{lc}
\hline & Dependent variable: $\log (\mathrm{CPI})$ \\
\hline Log(NEER) & $(1)$ \\
& $(1.60)$ \\
Log(Foreign price) & $1.46^{* * *}$ \\
& $(3.02)$ \\
Error Correction & $-0.10^{* * *}$ \\
& $(-2.92)$ \\
\hline Observations & 114 \\
\hline Numbers in parentheses are t-statistics. &,$* * *$ significant at $1 \%$
\end{tabular}

The error correction term $\left(e c_{e x t}\right)$, representing the long-run external market disequilibrium is as follows:

$$
e c_{e x t}=\theta_{1} p_{t}^{*}+\theta_{2} e_{t}-p_{t}
$$




$$
e c_{e x t}=p_{t}-1.46 p_{t}^{*}
$$

The error correction term completes the specification of a single-equation model.

\section{The single-equation inflation model}

The single-equation model includes both short-run and long-run inflation determinants. It combines error correction terms derived from the long-run equilibrium models in the money and external markets and the first differences of all variables used in the long-run equations. The single-equation model also includes lagged rainfall to control for supply shocks in agriculture. Various dummies capture events like the CFAF devaluation, the beginning of the oil era, and periods of political instability. The model also includes quarterly dummies to control for seasonality in inflation. Equation 8 illustrates the single-equation inflation model to be estimated with the ordinary least squares (OLS) method.

$$
\Delta p_{t}=\gamma_{0}+\sum_{i=1}^{k-1} \gamma_{1 i} \Delta x_{t-i}+\sum_{i=1}^{p} \gamma_{8 i} \text { rainfall }_{t-i}+\sum_{i=1}^{q} \gamma_{9 i} D_{t}+\gamma_{6}(e c)_{t-1}+\varepsilon_{t}
$$

$\Delta p_{t}$ represents the first difference of the logarithm of the CPI. All variables are expressed in logarithm terms except interest rates, rainfall, and dummies. $\Delta x_{t-i}$ includes the lags of the first differences of control variables such as the nominal effective exchange rate, foreign prices, domestic prices, real money, real GDP, and interest rates. Rainfall is the national average rainfall during the quarter, $D_{t}$ represents the set of dummies, and $e c$ the error correction terms.

A general-to-specific approach is used to obtain a parsimonious representation of inflation from Equation 8. The specification search of the inflation model does not retain real income as a main determinant of inflation. Given the likely significant impact of fiscal expansion on domestic inflation, the model includes a variable for public expenditure, aiming to capture the effect of the expansionary fiscal policy during the oil era.

\section{Results}

Estimations of the single-equation model show that the main drivers of inflation are rainfall, public spending, the nominal exchange rate, and foreign prices (Table 3).

Rainfall affects domestic prices through its impact on agriculture with a three-quarter lag; a 10 percent increase in rainfall reduces inflation by 0.35 percent three quarters later. This 
result indicates, as expected, the importance of rainfall, used as a proxy for agricultural production, in explaining inflation. ${ }^{7}$

Public spending affects inflation with a one-quarter lag; a 10 percent increase in public spending during one quarter increases inflation by 1 percent the following quarter. ${ }^{8}$ Higher government expenditure fuels domestic prices through demand pressures on nontradables. This result suggests that supply-side bottlenecks remain. ${ }^{9}$

The nominal exchange rate affects domestic prices with a one-quarter lag; a 10 percent appreciation (depreciation) of the nominal effective exchange rate decreases (increases) inflation by around 2.6 percent one quarter later. Despite the peg to the euro, a depreciation of the exchange rate with respect to non-euro trading partners contributes to inflationary pressures by increasing import prices. ${ }^{10}$

Changes in foreign prices are passed through in domestic prices via imports, with a onequarter lag; a 10 percent increase in foreign prices increases domestic inflation by 2 percent one quarter later. Absent adjustment in the exchange rate, higher prices in trading partners increases import prices, which spills over into domestic inflation. ${ }^{11}$

There is a varied degree of significance among control variables, capturing disequilibrium in the money and external markets, inflation seasonality, and the CFAF devaluation.

Money market disequilibrium does not affect inflation in Chad. The error correction term derived from the money market equilibrium is not significant in the single-equation model. Short-term factors in the money market, such as the real rate of return, are also not significant when introduced in the single-equation model. The explanation could be that, as Chad is a member of the CEMAC monetary union, the equilibrium in its own money market reflects

\footnotetext{
${ }^{7}$ This is consistent with Diouf (2007) which found that rainfall significantly explained inflation, especially with a two-quarter lag, in another sahelian country, Mali.

${ }^{8}$ In the case of oil-exporting countries such as Bahrain and Kuwait, Kandil and Morsy (2009) found that in the short run, public spending affects inflation by a similar magnitude and with a one-quarter lag.

${ }^{9}$ Efficient public investments, targeting structural bottlenecks, could ease capacity constraints and reduce price inflation in the long run.

${ }^{10}$ Evidence of a significant pass-through channel of the exchange rate to domestic prices has been highlighted for countries with fixed or non fixed exchange rate regimes. For instance, Diouf (2007) found that in Mali, about 33 percent of a nominal depreciation of the CFA franc vis-à-vis the dollar is reflected in domestic prices. In some GCC countries, which have pegged their domestic currencies to the U.S. dollar, Kandil and Morsy (2009) found that exchange rate depreciation tends to increase inflation. In Angola, Klein and Kyei (2009) also found that exchange rate movements drive inflation.

${ }^{11}$ Loening, Durevall, and Birru (2009) confirm that foreign prices explain domestic inflation in Ethiopia.
} 
CEMAC-wide rather than Chad-specific conditions. The very low level of monetization could also explain the limited role of the disequilibrium in the money market in explaining inflation.

However, external goods market disequilibrium contributes to inflation. The error correction term, derived from the external market equilibrium, significantly explains inflation. A 10 percent increase in the external market disequilibrium reduces inflation by 3 percent with a one-quarter lag. This result suggests that inflation movements help to close the gap between inflation and its equilibrium level as determined by the fundamentals in the external market.

Dummy variables confirm that inflation is seasonal and increased after the CFAF devaluation in 1994. The sign and the significance of quarterly dummies suggest that inflation is, on average, lower during the fourth quarter of the year. In particular, the second quarter is the highest inflationary period. The CFAF devaluation dummy is significant in specification 2, suggesting the positive effect of the devaluation on domestic inflation.

The single-equation model predicts actual inflation relatively well. Figures A.3-A.8 illustrate the changes in the actual and predicted CPI as well as the residuals of the inflation models. The possibility of an omitted variable bias is therefore not severe. Various tests (misspecification, normality, heteroskedasticity, and autoregressive heteroskedasticity) analyzing some properties of the models do not reveal any particular problem (Table A.6).

The single-equation model does not fully capture inflation persistence. As highlighted by Coleman (2010), inflation persistence could be present in Chad. In fact, the effect of rainfall, public spending, nominal effective exchange rate, and foreign prices on inflation could last after the first, second, or third quarter, reflecting second round effects.

To capture inflation persistence, the next section of the paper applies a structural vector autoregression model, which analyzes the impact and the persistence of diverse economic shocks on inflation. In addition, the SVAR allows a better handling of possible interrelation among variables that could affect the estimated coefficients with the single-equation model. 
Table 3. Chad: Inflation Model

\begin{tabular}{|c|c|c|c|}
\hline & \multicolumn{3}{|c|}{ Dependent variable: $\Delta(\log \mathrm{CPI})$} \\
\hline & (1) & (2) & $(3)^{1}$ \\
\hline$\Delta(\text { foreign price })_{t-1}$ & $\begin{array}{l}0.183 \\
(1.69) *\end{array}$ & $\begin{array}{l}0.198 \\
(1.82) *\end{array}$ & $\begin{array}{l}0.209 \\
(1.93) *\end{array}$ \\
\hline$\Delta(\mathrm{NEER})_{\mathrm{t}-1}$ & $\begin{array}{l}-0.252 \\
(4.05)^{* * * *}\end{array}$ & $\begin{array}{l}-0.262 \\
(4.17)^{* * *}\end{array}$ & $\begin{array}{l}-0.269 \\
(4.30)^{* * *}\end{array}$ \\
\hline$\Delta(\text { Public exp. })_{\mathrm{t}-1}$ & $\begin{array}{l}0.093 \\
(2.10)^{* *}\end{array}$ & $\begin{array}{l}0.093 \\
(2.03)^{* *}\end{array}$ & $\begin{array}{l}0.095 \\
(2.09)^{* *}\end{array}$ \\
\hline Rainfall $_{t-3}$ & $\begin{array}{l}-0.036 \\
(2.82)^{* * *}\end{array}$ & $\begin{array}{l}-0.033 \\
(2.58)^{* *}\end{array}$ & $\begin{array}{l}-0.035 \\
(2.70)^{* * *}\end{array}$ \\
\hline Constant & $\begin{array}{l}-0.035 \\
(4.04)^{* * * *}\end{array}$ & $\begin{array}{l}-0.027 \\
(3.43)^{* * *}\end{array}$ & $\begin{array}{l}-0.032 \\
(3.74)^{* * *}\end{array}$ \\
\hline$E C_{e x t}$ & $\begin{array}{l}-0.281 \\
(2.40)^{* *}\end{array}$ & $\begin{array}{l}-0.266 \\
(2.25)^{* *}\end{array}$ & $\begin{array}{l}-0.291 \\
(2.44)^{* *}\end{array}$ \\
\hline Quarter 1 & $\begin{array}{l}0.198 \\
(3.04)^{* * *}\end{array}$ & $\begin{array}{l}0.183 \\
(2.80)^{* * *}\end{array}$ & $\begin{array}{l}0.192 \\
(2.92)^{* * *}\end{array}$ \\
\hline Quarter 2 & $\begin{array}{l}0.280 \\
(3.46)^{* * *}\end{array}$ & $\begin{array}{l}0.262 \\
(3.21)^{* * * *}\end{array}$ & $\begin{array}{l}0.273 \\
(3.33)^{* * *}\end{array}$ \\
\hline Quarter 3 & $\begin{array}{l}0.188 \\
(4.14)^{* * * *}\end{array}$ & $\begin{array}{l}0.178 \\
(3.89)^{* * *}\end{array}$ & $\begin{array}{l}0.184 \\
(4.01)^{* * *}\end{array}$ \\
\hline Devaluation dummy & $\begin{array}{l}0.018 \\
(2.07)^{* *}\end{array}$ & & $\begin{array}{l}0.013 \\
(1.44)\end{array}$ \\
\hline R-squared & 0.49 & 0.47 & 0.48 \\
\hline Observations & 114 & 114 & 114 \\
\hline $\begin{array}{l}\text { Robust } t \text { statistics are in } \mathrm{p} \\
* \text { significant at } 10 \% ; * * \mathrm{~s} \\
\text { All regressions include qu } \\
\text { the reference quarter and } \\
\text { Political instability and oi }\end{array}$ & $\begin{array}{l}* * * \text { signi } \\
\text { a dumm } \\
\text { cluded it } \\
\text { e not sigr }\end{array}$ & Ind polit & . Quarter 4 is \\
\hline
\end{tabular}

\section{Structural Vector Autoregression Model}

SVAR results confirm the main determinants of inflation (rainfall, public spending, nominal exchange rate, and foreign prices) and show that their effects persist over few quarters (Figure 4).

The SVAR isolates structural shocks in the VAR system by imposing restrictions suggested by economic theory. The SVAR assumes that the economy behaves recursively, as described by the following five equations: 


$$
\begin{gathered}
\operatorname{Rain}_{\mathrm{t}}=E_{t-1} \operatorname{Rain}_{\mathrm{t}}+\mathrm{u}_{\mathrm{t}}^{\mathrm{r}} \\
\Delta \mathrm{p}_{\mathrm{t}}^{*}=E_{t-1} \Delta \mathrm{p}_{\mathrm{t}}^{*}+\alpha_{1} \mathrm{u}_{\mathrm{t}}^{\mathrm{r}}+\mathrm{u}_{\mathrm{t}}^{\mathrm{p} *} \\
\Delta \mathrm{e}_{\mathrm{t}}=E_{t-1} \Delta \mathrm{e}_{\mathrm{t}}+\alpha_{2} \mathrm{u}_{\mathrm{t}}^{\mathrm{r}}+\alpha_{3} \mathrm{u}_{\mathrm{t}}^{\mathrm{p} *}+\mathrm{u}_{\mathrm{t}}^{\mathrm{e}} \\
\Delta \mathrm{g}_{\mathrm{t}}=E_{t-1} \Delta \mathrm{g}_{\mathrm{t}}+\alpha_{4} \mathrm{u}_{\mathrm{t}}^{\mathrm{r}}+\alpha_{5} \mathrm{u}_{\mathrm{t}}^{\mathrm{p}}+\alpha_{6} \mathrm{u}_{\mathrm{t}}^{\mathrm{e}}+\mathrm{u}_{\mathrm{t}}^{\mathrm{g}} \\
\Delta \mathrm{p}_{\mathrm{t}}=E_{t-1} \Delta \mathrm{p}_{\mathrm{t}}+\alpha_{7} \mathrm{u}_{\mathrm{t}}^{\mathrm{r}}+\alpha_{8} \mathrm{u}_{\mathrm{t}}^{\mathrm{p} *}+\alpha_{9} \mathrm{u}_{\mathrm{t}}^{\mathrm{e}}+\alpha_{10} \mathrm{u}_{\mathrm{t}}^{\mathrm{g}}+\mathrm{u}_{\mathrm{t}}^{\mathrm{p}}
\end{gathered}
$$

$\Delta$ and $E$ respectively represent the first difference and the conditional expectation operator. Rain, $p_{t}^{*}, e_{t}, g_{t}$, and $p_{t}$ respectively represent rainfall, foreign prices, nominal effective exchange rate, public spending, and domestic prices. $\alpha_{1}$ represents the estimated coefficients. The system assumes rainfall (Rain) is exogenous and affects other disturbances in the system (Equations 9-13). Foreign prices shocks $\left(\mathrm{u}^{\mathrm{p} 8}\right)$ affect disturbances of variables other than rainfall (equation 10-13). Shocks in the nominal effective exchange rate $\left(\mathrm{u}^{\mathrm{e}}\right)$ affect disturbances of public spending and domestic inflation (equation 11-13). Public spending shocks affect only disturbances of domestic inflation (equation 12-13). Assuming expectations depend on past realizations, we replace the conditional expectations in the system by linear projections of lags ${ }^{12}$ of the five variables in the system. ${ }^{13}$

A positive shock in rainfall reduces inflation and the effect persists over six quarters. The impact of a rainfall shock on inflation is at its maximum three quarters after the shock, confirming the result of the single-equation model. The SVAR impulse response highlights that the effect of the rainfall shock is persistent. An increase in rainfall reduces inflation between the first and the sixth quarter. The impact increases between the first and the third quarter, reaches its maximum during the third quarter, and decreases gradually until it becomes insignificant around the sixth quarter.

An increase in foreign prices also pushes up inflation during six quarters. The impact of higher foreign prices on inflation is at its maximum during the first quarter, confirming the results of the single-equation model. After the first quarter, the impact of the increase in foreign prices decreases gradually until it becomes insignificant around the sixth quarter.

A nominal appreciation of the exchange rate reduces inflation during four quarters following the appreciation. The nominal appreciation has its highest effect on inflation with a lag of

\footnotetext{
${ }^{12}$ The choice of lag length is based on the Schwarz Information Criterion (SIC).

${ }^{13}$ As in the single-equation model, the SVAR includes various dummies as exogenous variables to control for inflation seasonality.
} 
two quarters, one quarter later than predicted by the single-equation model. After the second quarter, the impact of the nominal appreciation gradually decreases until it becomes insignificant around the fourth quarter.

Higher public spending increases inflation between the first and the third quarter. The effect of an increase in public investment on inflation is at its highest around the second and third quarters, one or two quarters later than predicted by the single-equation model.

Figure 4. Chad: Impulse Response of Inflation

\section{Response of Inflation to Rainfall Shock}

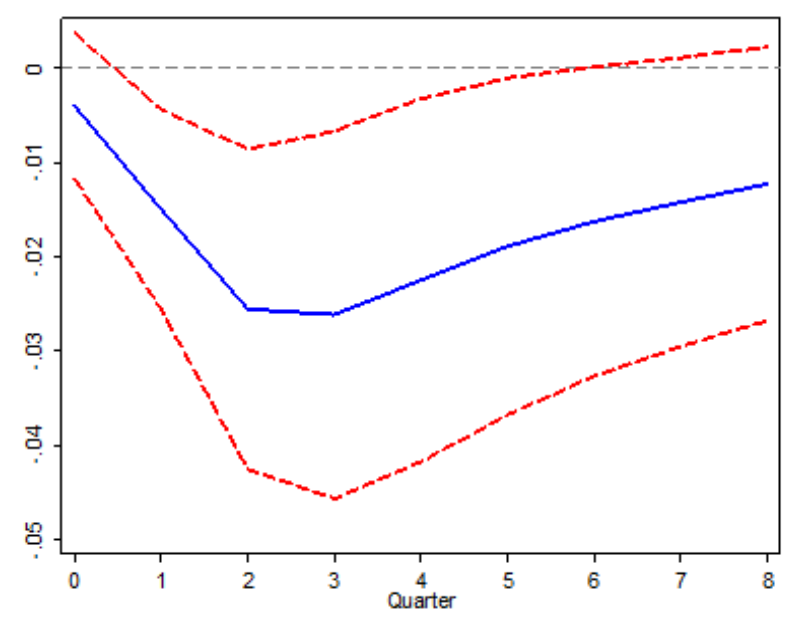

Response of Inflation to Nominal Appreciation

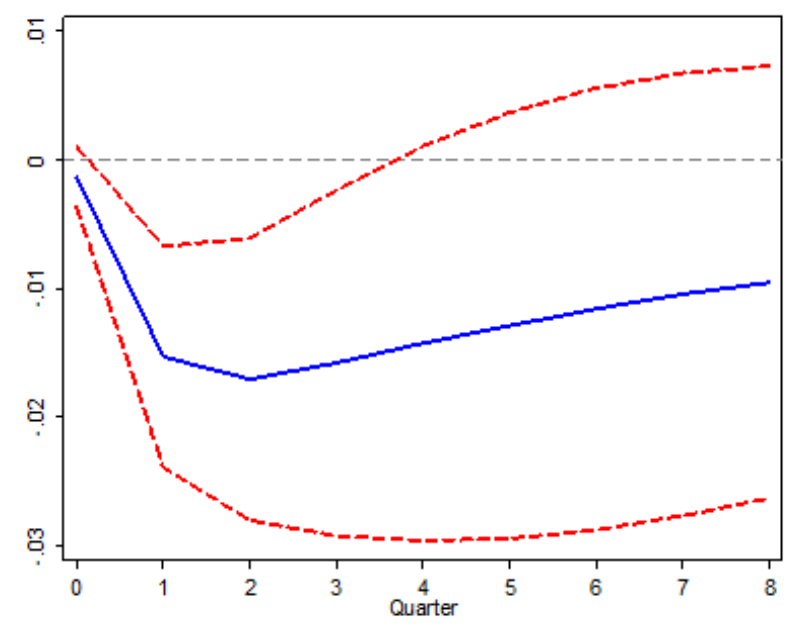

Response of Inflation to Foreign Prices Shock

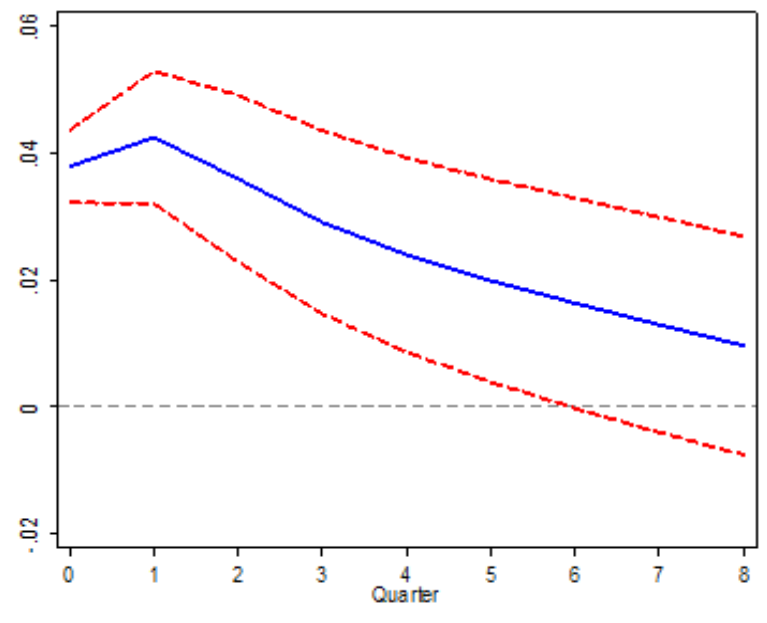

Response of Inflation to Public Spending Shock

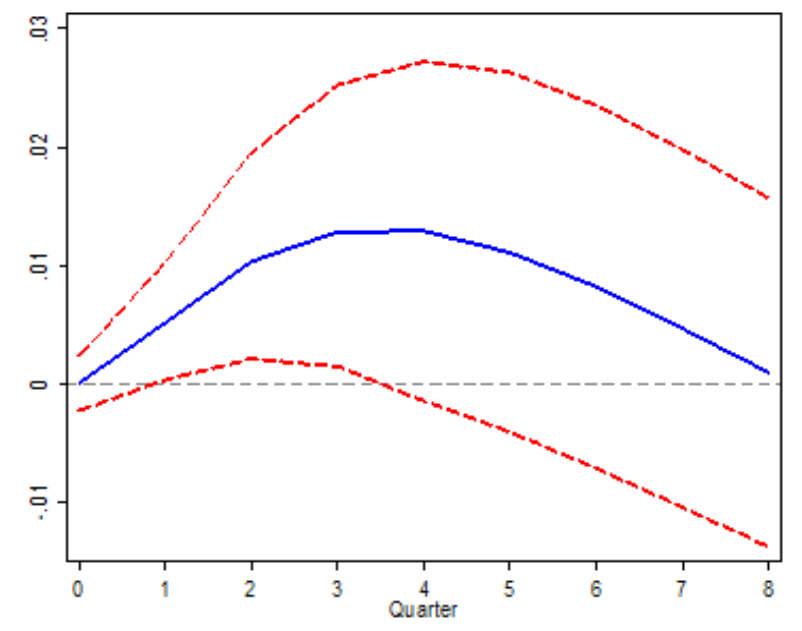

Dashed lines represent 95\% lower and upper bounds. 


\section{Conclusion}

This paper analyzes the determinants of inflation in Chad, highlighting the role of monetary and external factors. The empirical analysis is based primarily on a single-equation model, supplemented by an SVAR model to investigate inflation persistence. The empirical analysis also controls for supply-side constraints, institutional factors, and major historical events such as the devaluation of the CFAF in 1994 and the start of oil production in 2003.

The results show that the main drivers of inflation in Chad are rainfall, foreign prices, exchange rate movements, and public spending. Rainfall affects domestic prices through its impact on agriculture. An increase in rainfall reduces inflation during the following six quarters although the effect is highest during the third quarter. Changes in foreign prices and the nominal effective exchange rate also affect domestic prices through a pass-through to import prices. Higher foreign prices increase inflation during six quarters after the shock; the maximum impact occurs during the first quarter. A nominal appreciation of the exchange rate reduces inflation during four quarters with the highest effect during the second quarter. Public spending, fueled by oil production since 2003, has a significant impact on inflation through demand pressures on nontradables. Higher public spending increases inflation between the first and the third quarter; the maximum impact occurs around the second and third quarter.

The inflationary effects of rainfall and public spending could be mitigated with domestic policy effort. The results suggest that improved efficiency in agriculture, storage and transportation would reduce the role of rainfall. Improving food storage facilities would indeed help to prevent significant increases in food prices following natural disasters such as droughts or floods. Reducing market segmentation and liberalizing internal and external trade through an improvement in transportation infrastructure such as rural roads would also help to limit pressure stemming from excess demand. Enhancing agricultural productivity through the use of modern techniques, such as irrigation and improved seeds, and the better access to rural credits would also help improve agricultural production and reduce pressures on prices.

Better control of public expenditures is also key to maintaining low inflation in Chad. This could be achieved by improving public financial management through better investment planning and procurement practices as well as by integrating the inflationary effect of public expenditures when designing public spending programs. 


\section{REFERENCES}

Barnichon, Regis, and Shanaka J. Peiris, 2008, "Sources of Inflation in Sub-Saharan Africa," Journal of African Economies, 17(5): 729-46.

Blavy, Rodolphe, 2004, "Inflation and Monetary Pass-Through in Guinea," IMF Working Paper 04/223 (Washington: International Monetary Fund).

Bloem, Adriaan M., Robert J. Dippelsman, and Nils O. Maehle, 2001, Quarterly National Accounts Manual: Concepts, Data Sources, and Compilation (Washington: International Monetary Fund), available via the Internet: http://www.imf.org/external/pubs/ft/qna/2000/Textbook/index.htm

Chibber, A., and N. Shafik, 1990, "Exchange Reform, Parallel Markets, and Inflation in Africa: A Case of Ghana," World Bank Policy Working Papers 47 (Washington: World Bank).

Coleman, Simeon, 2010, "Inflation Persistence in the Franc Zone: Evidence from Disaggregated Prices," Journal of Macroeconomics, 32(1): 426-442.

Diouf, Mame Astou, 2007, “Modeling Inflation for Mali,” IMF Working Paper 07/295 (Washington: International Monetary Fund).

Gottschalk, Jan, Kadima Kalonji, and Ken Miyajima, 2008, "Analyzing Determinants of Inflation When There Are Data Limitations: The Case of Sierra Leone," IMF Working Paper 08/271 (Washington: International Monetary Fund).

Juselius, K., 1992, "Domestic and Foreign Effects on Prices in an Open Economy: The Case of Denmark," Journal of Policy Modeling, 14(4): 401-428.

Kandil, Magda, and Hanan Morsy, 2009, "Determinants of Inflation in GCC," IMF Working Paper 09/82 (Washington: International Monetary Fund).

Klein, Nir, and Alexander Kyei, 2009, “Understanding Inflation Inertia in Angola," IMF Working Paper 09/98 (Washington: International Monetary Fund).

Loening, Josef L., Durevall Dick, and Birru Yohannes A., 2009, "Inflation Dynamics and Food Prices in an Agricultural Economy: The Case of Ethiopia," Policy Research Working Paper 4969 (Washington: The World Bank).

Miguel, Edward, Shanker Satyanath, and Ernest Sergenti, 2004, "Economic Shocks and Civil Conflict: An Instrumental Variables Approach," Journal of Political Economy, 112(4): 725-53. 
Montenegro, Claudio E., and Maximilian L. Hirn, 2009, "A New Disaggregated Set of Labor Market Indicators Using Standardized Household Surverys from Around the World," World Development Report 2009 (Reshaping Economic Geography) Background Paper (Washington: World Bank).

Moriyama, Kenji, 2008, “Investigating Inflation Dynamics in Sudan,” IMF Working Paper 08/189 (Washington: International Monetary Fund).

Nassar, Koffie, 2005, “Money Demand and Inflation in Madagascar," IMF Working Paper 05/236 (Washington: International Monetary Fund).

Ubide, Angel, 1997, “Determinants of Inflation in Mozambique,” IMF Working Paper 97/145 (Washington: International Monetary Fund). 


\section{APPENDIX}

Table A.1. Chad: Weights of the Components/Subcomponents of the CPI

\begin{tabular}{lr}
\hline Components/Subcomponents & Weight \\
\hline Food and non alcoholic beverages & 46.18 \\
Bread and Cereals & 17.24 \\
Meat & 7.85 \\
Fish & 3.64 \\
Milk, Cheese, and Eggs & 1.49 \\
Oils and Fats & 3.74 \\
Vegetables and Tubers & 3.67 \\
Alcoholic beverages and tobacco & 3.08 \\
Clothing and shoes & 10.88 \\
Housing, water, gas, electricity, and other fuels & 13.31 \\
Furniture, houseware, and house maintenance & 4.23 \\
Health & 2.73 \\
Transportation & 6.36 \\
Communications & 2.35 \\
Leisure and culture & 3.55 \\
Education & 0.96 \\
Other goods and services & 1.74 \\
Restaurants et hotels & 4.63 \\
\hline Total & 100 \\
\hline
\end{tabular}


Table A.2. Chad: Definitions and Sources of Variables

\begin{tabular}{|c|c|c|}
\hline Variable & Definition & Source \\
\hline $\log (\mathrm{CPI})$ & $\begin{array}{l}\text { Logarithm of consumer price } \\
\text { index }\end{array}$ & INSEED \\
\hline $\log ($ NEER) & $\begin{array}{l}\text { Logarithm of nominal } \\
\text { effective exchange rate }\end{array}$ & IMF Effective Exchange Rate Facility \\
\hline $\log ($ Foreign price $)$ & $\begin{array}{l}\text { Logarithm of foreign } \\
\text { effective price level }\end{array}$ & IMF Effective Exchange Rate Facility \\
\hline Discount rate & BEAC discount rate & International Financial Statistics (IFS) \\
\hline Deposit rate & Interest rate on time deposits & IFS \\
\hline Log(Real Money) & $\begin{array}{l}\text { Logarithm of real broad } \\
\text { money (money and quasi } \\
\text { money) }\end{array}$ & IFS \\
\hline $\begin{array}{l}\text { Log(Government } \\
\text { expenditures) }\end{array}$ & $\begin{array}{l}\text { Logarithm of government } \\
\text { expenditures }\end{array}$ & World Economic Outlook (WEO) \\
\hline Log(Real GDP) & Logarithm of Real GDP & WEO \\
\hline $\log (\mathrm{ToT})$ & Logarithm of terms of trade & WEO \\
\hline $\log ($ Rainfall $)$ & $\begin{array}{l}\text { Logarithm of Average } \\
\text { national rainfall in mm. }\end{array}$ & $\begin{array}{l}\text { Direction des Ressources en Eau et de la } \\
\text { Météorologie, Division de la Climatologie } \\
\text { (Octobre 2009) and Miguel, Satyanath, and } \\
\text { Sergenti (2004). }\end{array}$ \\
\hline Political instability dummy & $\begin{array}{l}\text { Dummy equal } 1 \text { during } \\
\text { period of political instability } \\
\text { such as rebels' assaults }\end{array}$ & $\begin{array}{l}\text { Polity IV and } \\
\text { http://www.jeuneafrique.com/Chronologie- } \\
\text { pays } 84 \text { Tchad }\end{array}$ \\
\hline Devaluation dummy & $\begin{array}{l}\text { Dummy equal } 1 \text { after the } \\
\text { devaluation in } 1994\end{array}$ & \\
\hline Oil era dummy & $\begin{array}{l}\text { Dummy equal } 1 \text { after the start } \\
\text { of oil production in } 2003\end{array}$ & \\
\hline Quarter & Quarterly dummies & \\
\hline
\end{tabular}


Table A.3. Chad: Unit Root Test

\begin{tabular}{|c|c|c|c|c|}
\hline & \multicolumn{2}{|c|}{$\mathrm{ADF}$} & \multicolumn{2}{|c|}{ Phillips-Perron } \\
\hline & Statistics & P-value & Statistics & P-value \\
\hline \multicolumn{5}{|l|}{ In level } \\
\hline $\log (\mathrm{CPI})$ & -0.18 & 0.94 & -0.31 & 0.92 \\
\hline Log (NEER) & -1.75 & 0.40 & -1.81 & 0.37 \\
\hline Log(Foreign price) & -2.71 & 0.07 & -2.86 & 0.05 \\
\hline Discount rate & -1.60 & 0.48 & -0.96 & 0.77 \\
\hline Deposit rate & -1.13 & 0.70 & -1.91 & 0.33 \\
\hline Log(Real Money) & -0.79 & 0.82 & -0.44 & 0.90 \\
\hline Log(Gov. expenditures) & -1.02 & 0.74 & -1.03 & 0.74 \\
\hline Log(Real GDP) & 1.38 & 0.99 & 0.368 & 0.98 \\
\hline $\log (\mathrm{ToT})$ & -1.58 & 0.49 & -1.57 & 0.50 \\
\hline \multicolumn{5}{|l|}{ In first difference } \\
\hline $\log (\mathrm{CPI})$ & -8.99 & 0.00 & -8.88 & 0.00 \\
\hline Log (NEER) & -10.91 & 0.00 & -10.91 & 0.00 \\
\hline Log(Foreign price) & -8.50 & 0.00 & -8.33 & 0.00 \\
\hline Discount rate & -9.76 & 0.00 & -9.74 & 0.00 \\
\hline Deposit rate & -9.50 & 0.00 & -9.49 & 0.00 \\
\hline Log(Real Money) & -11.08 & 0.00 & 11.40 & 0.00 \\
\hline Log(Gov. expenditures) & -3.58 & 0.01 & -4.15 & 0.00 \\
\hline Log(Real GDP) & -2.34 & 0.15 & -3.41 & 0.01 \\
\hline $\log (\mathrm{ToT})$ & -3.0 & 0.03 & -3.99 & 0.00 \\
\hline
\end{tabular}


Figure A.1. Chad: Evolution of the Main Variables

Log (NEER)

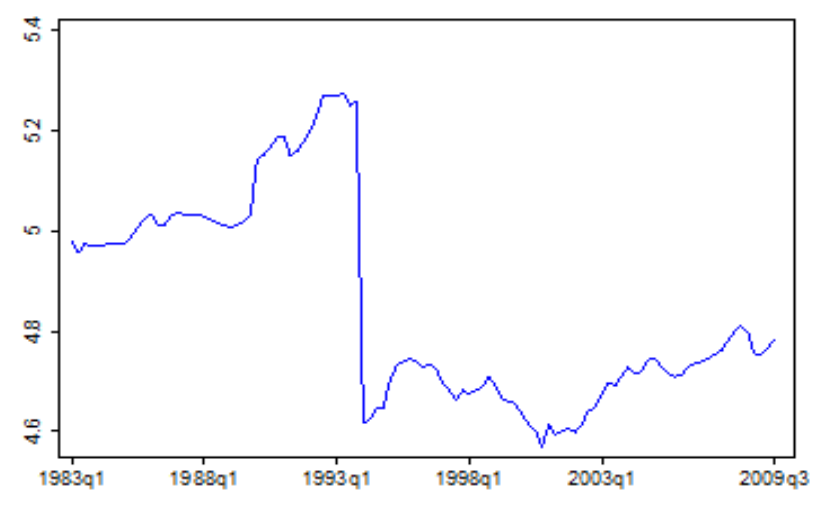

Discount and deposit rate

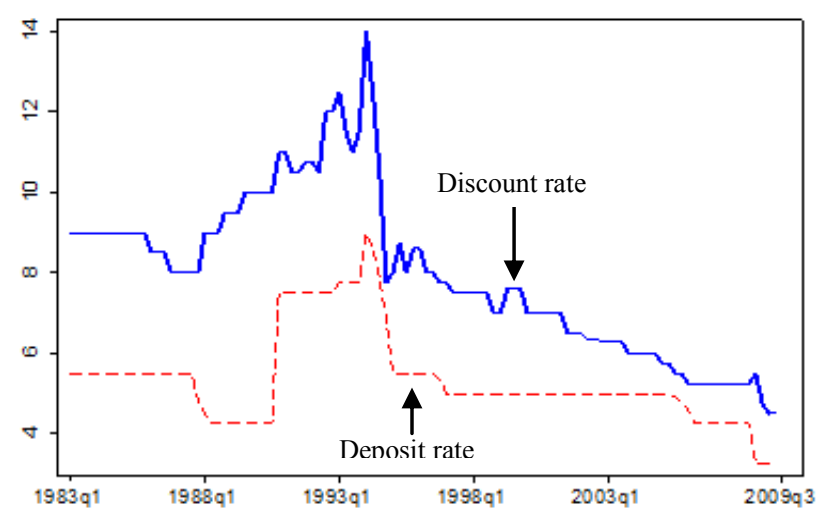

Log (Real broad money)

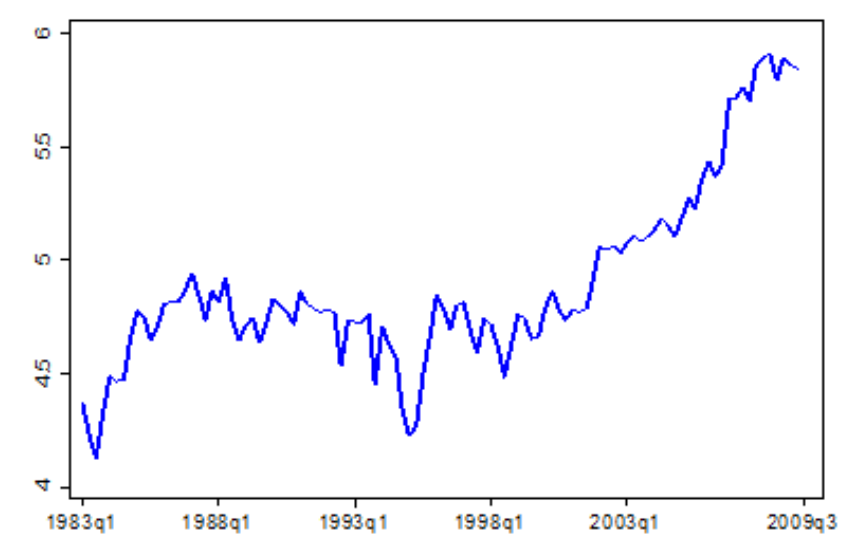

$\log ($ Government expenditures)

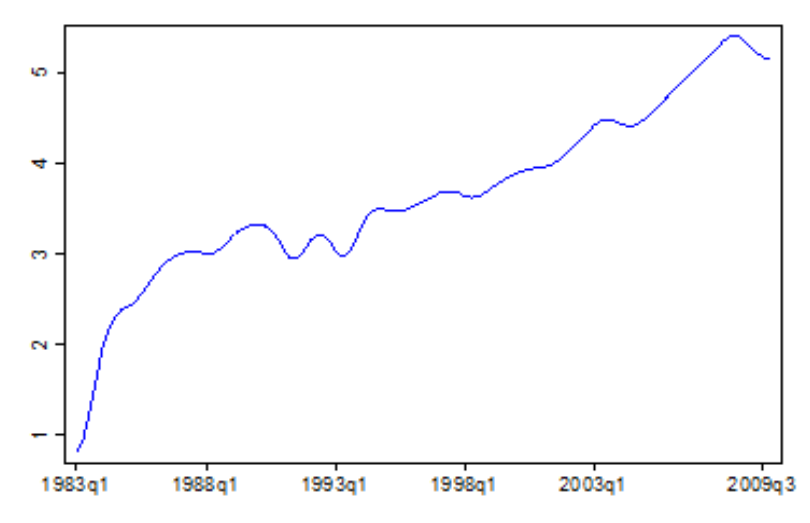

$\log ($ Foreign price $)$

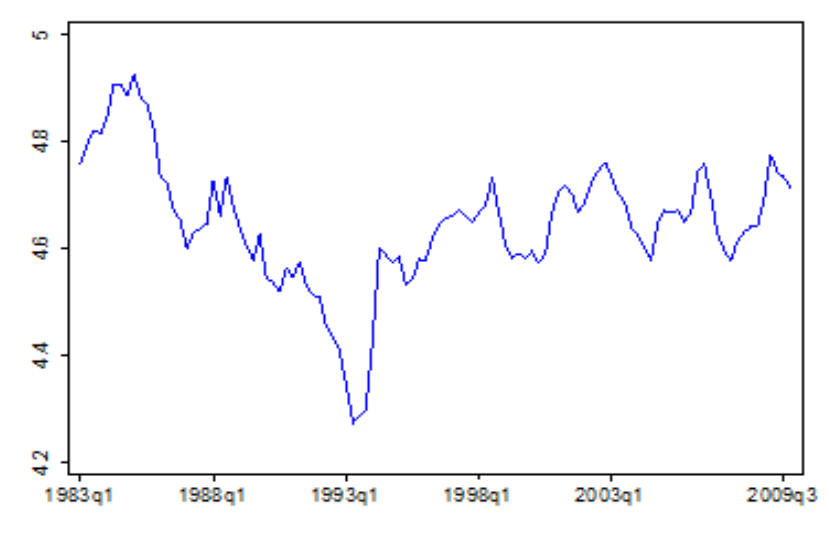

$\log ($ Real GDP)

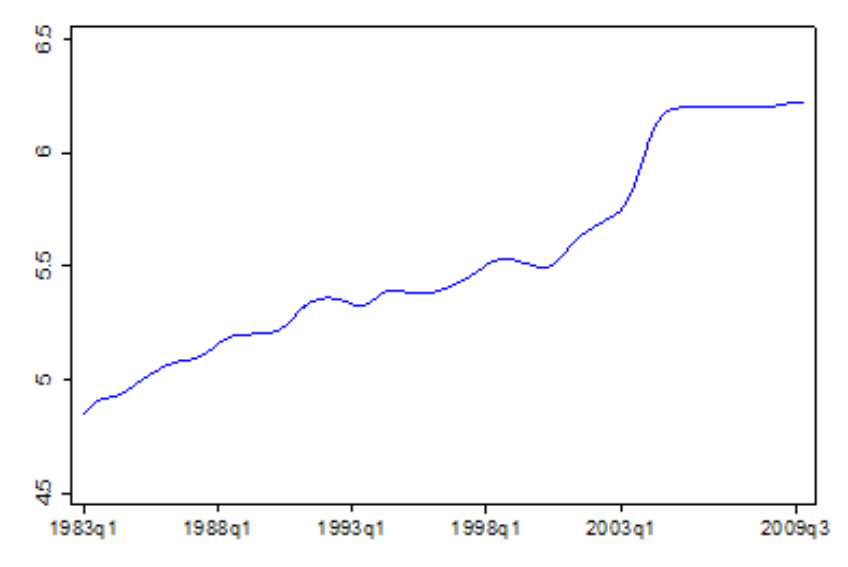


Figure A.2. Chad: Four-Quarter Lag Moving Average of the National Rainfall and CPI

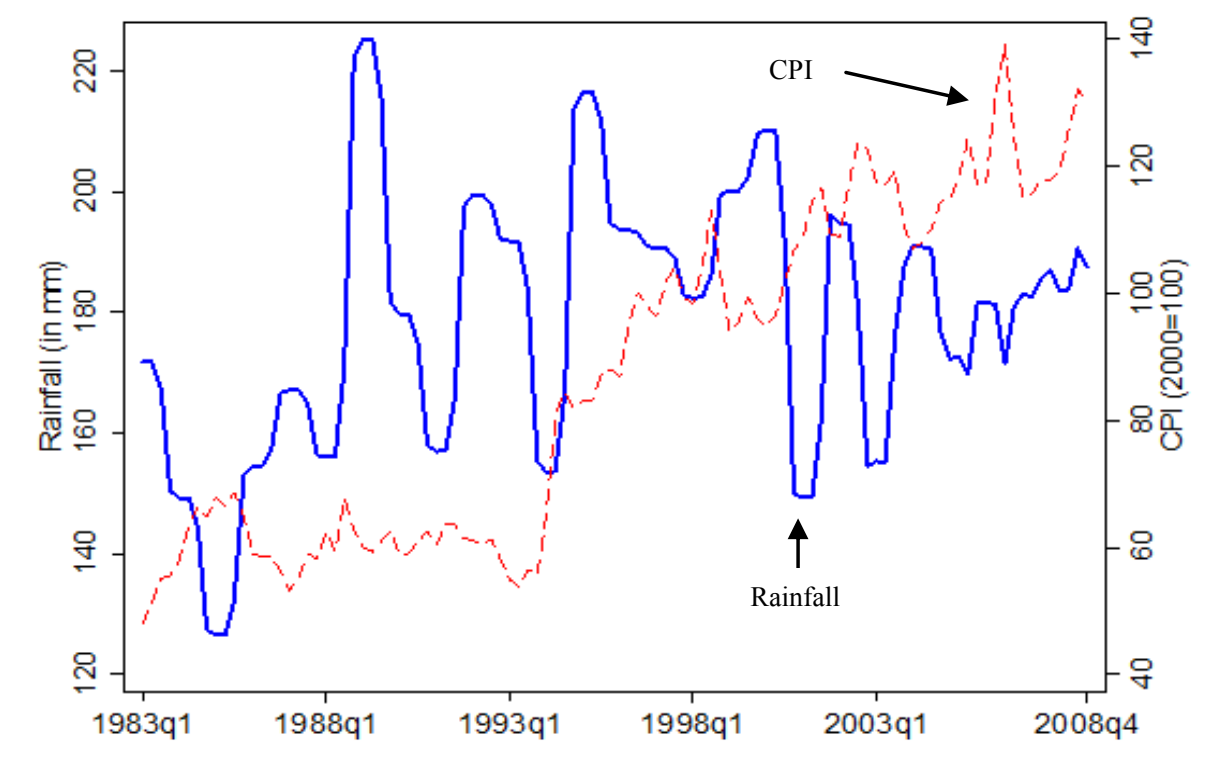


Table A.4. Chad: Johansen Cointegration Test, Money Market Equilibrium

\begin{tabular}{cccccc}
\hline \multicolumn{2}{c}{ Maximum } & & & Trace & Critical \\
rank & parms & LL & Eigenvalue & statistic & value (5\%) \\
\hline 0 & 84 & 559.9 & & 64.1 & 63.0 \\
1 & 92 & 574.3 & 0.2 & $35.3^{*}$ & 42.4 \\
2 & 98 & 583.3 & 0.2 & 17.3 & 25.3 \\
3 & 102 & 589.2 & 0.1 & 5.4 & 12.3 \\
4 & 104 & 591.9 & 0.1 & & \\
\hline \multicolumn{6}{r}{ Maximum } \\
rank & parms & LL & Eigenvalue & statistic & value (5\%) \\
\hline 0 & 84 & 559.9 & & 28.9 & 31.5 \\
1 & 92 & 574.3 & 0.2 & 18.0 & 25.5 \\
2 & 98 & 583.3 & 0.2 & 11.9 & 19.0 \\
3 & 102 & 589.2 & 0.1 & 5.4 & 12.5 \\
4 & 104 & 591.9 & 0.1 & & \\
\hline
\end{tabular}

*The null hypothesis that there is one cointegrating equation is not rejected.

Table A.5. Chad: Johansen Cointegration Test, External Market Equilibrium

\begin{tabular}{cccccc}
\hline \multicolumn{2}{c}{ Maximum } & & & Trace & Critical \\
Rank & Parms & LL & Eigenvalue & statistic & value 5\% \\
\hline 0 & 105 & 1058.0 & & 71.1 & 68.5 \\
1 & 114 & 1071.8 & 0.2 & $43.4^{*}$ & 47.2 \\
2 & 121 & 1080.6 & 0.2 & 26.0 & 29.7 \\
3 & 126 & 1088.6 & 0.1 & 9.8 & 15.4 \\
4 & 129 & 1092.4 & 0.1 & 2.3 & 3.8 \\
5 & 130 & 1093.5 & 0.0 & & Critical \\
\hline \multicolumn{6}{r}{ Maximum } \\
Rank & Parms & LL & Eigenvalue & statistic & value 5\% \\
\hline 0 & 105 & 1058.0 & & 27.7 & 33.5 \\
1 & 114 & 1071.8 & 0.2 & 17.4 & 27.1 \\
2 & 121 & 1080.6 & 0.2 & 16.1 & 21.0 \\
3 & 126 & 1088.6 & 0.1 & 7.6 & 14.1 \\
4 & 129 & 1092.4 & 0.1 & 2.3 & 3.8 \\
5 & 130 & 1093.5 & 0.0 & & \\
\hline
\end{tabular}

*The null hypothesis that there is one cointegrating equation is not rejected. 
Figure A.3. Chad: Actual and Predicted Quarterly Inflation (Specification 1)

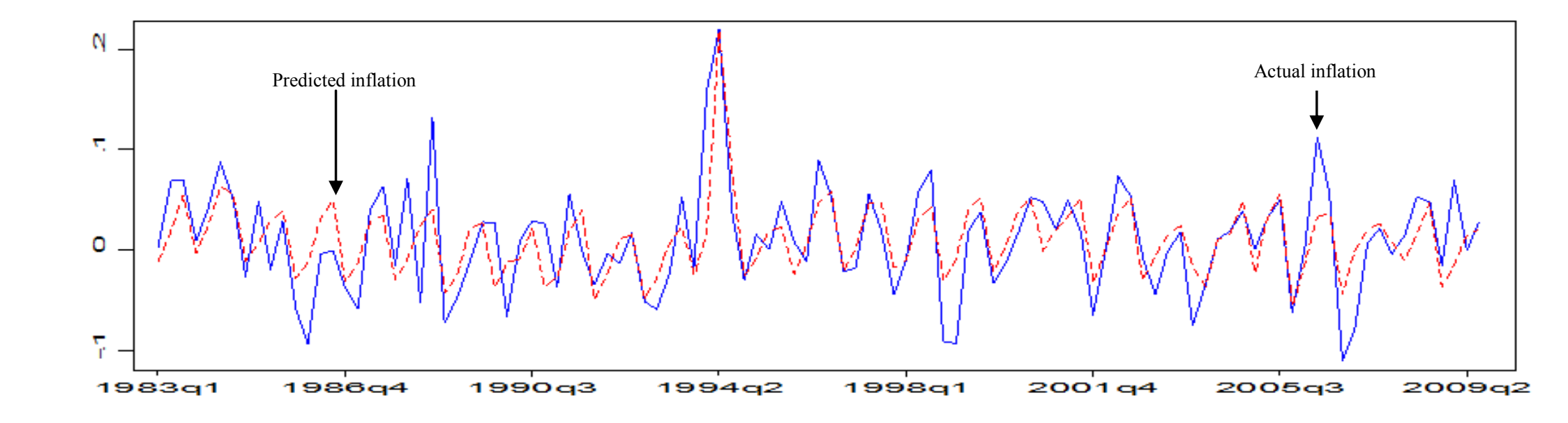

Figure A.4. Chad: Residuals (Specification 1)

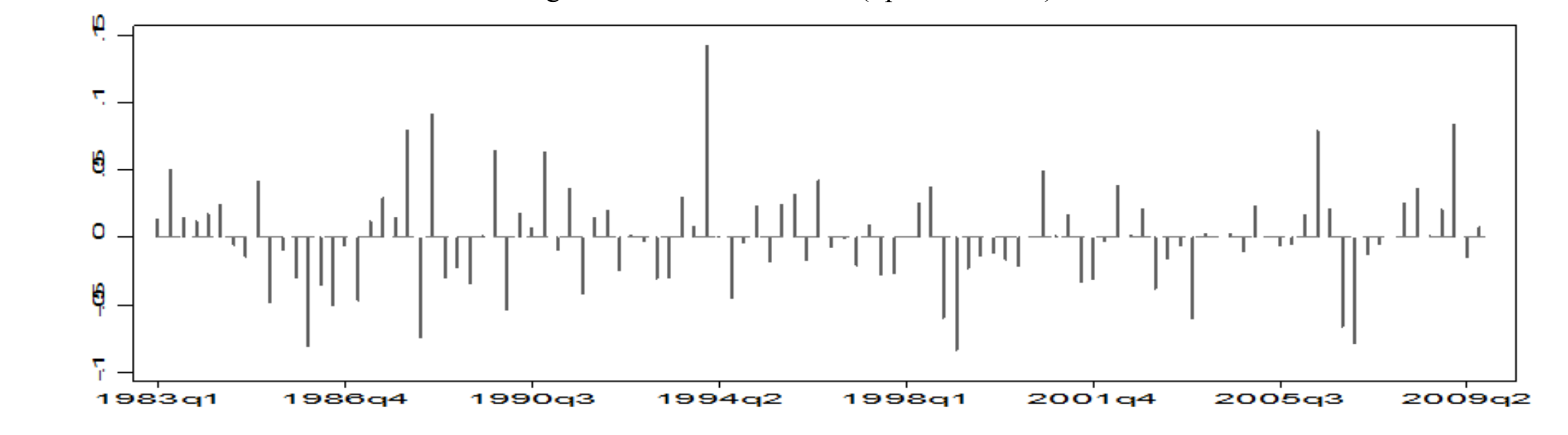


Figure A.5. Chad: Actual and Predicted Quarterly Inflation (Specification 2)

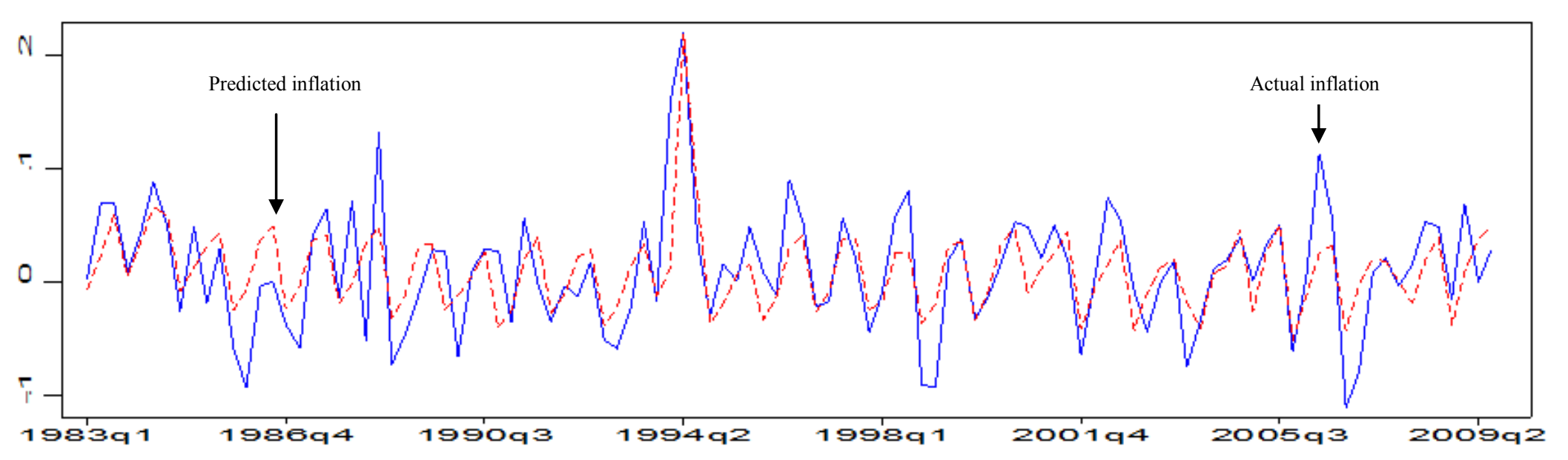

Figure A.6. Chad: Residuals (Specification 2)

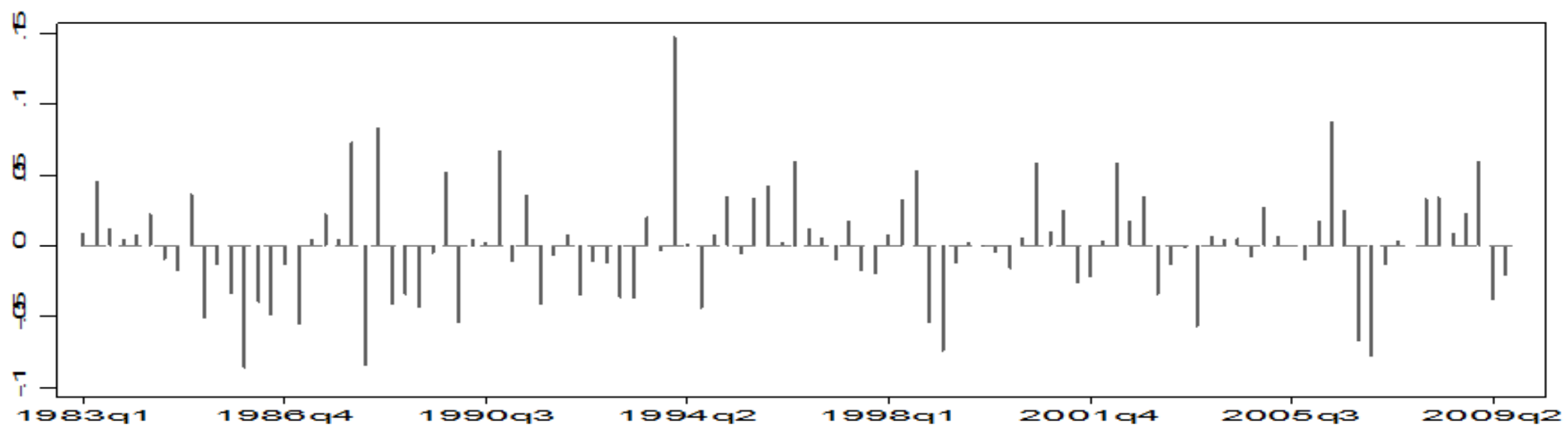


Figure A.7. Chad: Actual and Predicted Quarterly Inflation (Specification 3)

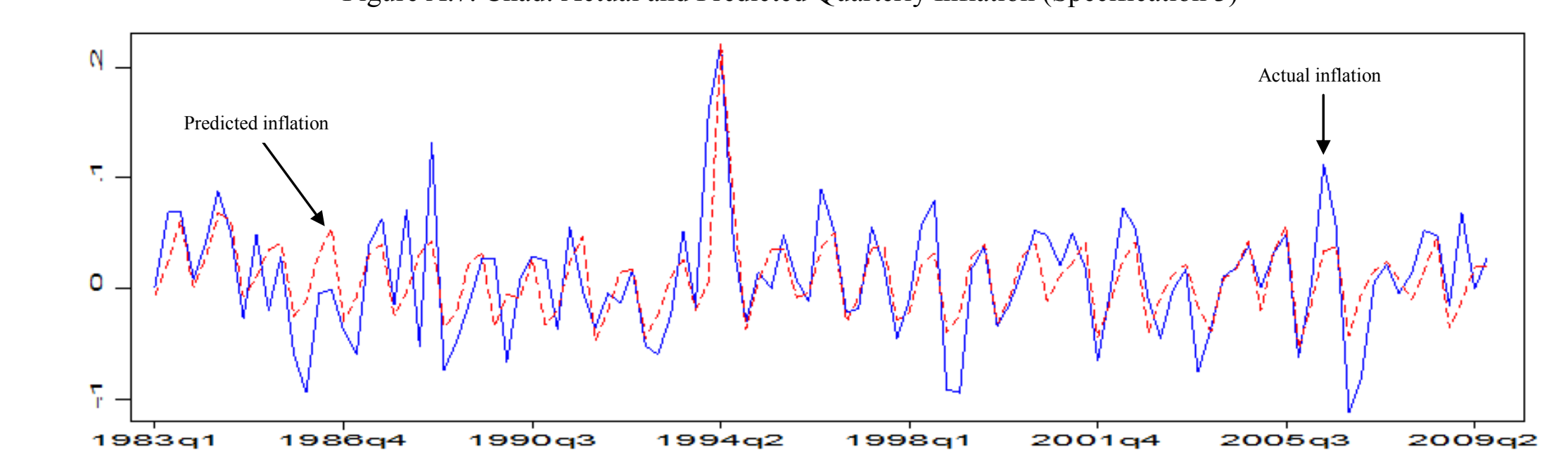

Figure A.8. Chad: Residuals (Specification 3)

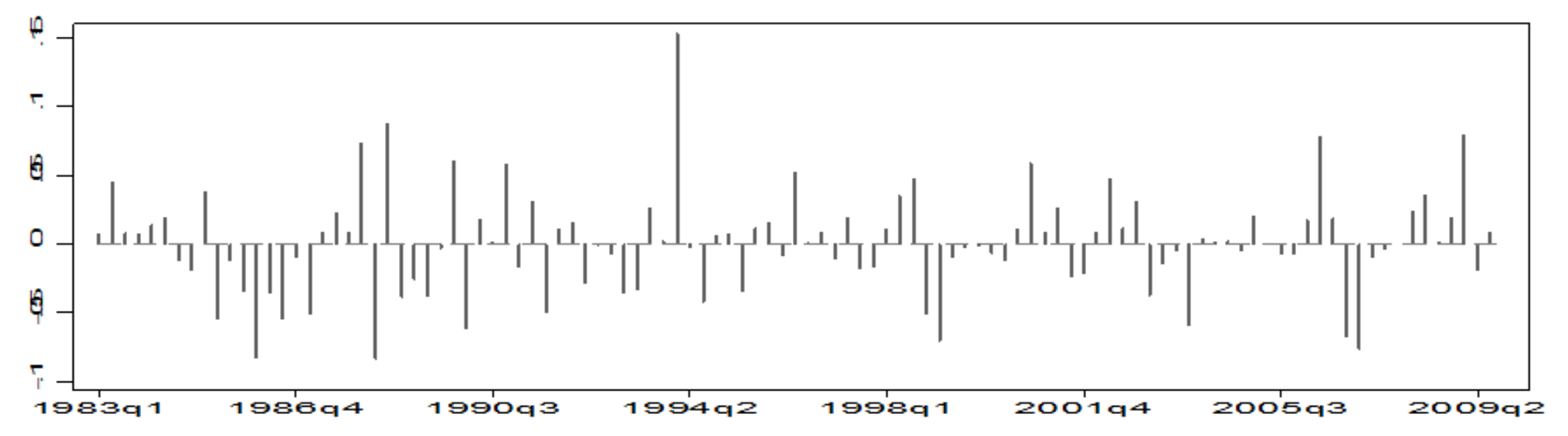


Table A.6. Chad: Diagnostic Statistics for the Single-Equation Inflation Models

\begin{tabular}{cccccccc}
\hline & $\begin{array}{c}\text { Breusch-Pagan / } \\
\text { Cook-Weisberg test } \\
\text { for heteroskedasticity }\end{array}$ & $\begin{array}{c}\text { Ramsey } \\
\text { RESET }\end{array}$ & Skewness & Kurtosis & $\begin{array}{c}\text { ARCH } \\
\text { (1 lag) }\end{array}$ & $\begin{array}{c}\text { ARCH } \\
\text { (2 lags) }\end{array}$ & $\begin{array}{c}\text { ARCH } \\
\text { (3 lags) }\end{array}$ \\
\hline Specification 1 & 0.86 & 0.56 & 6.08 & 1.46 & 0.027 & 0.173 & 0.223 \\
& $(0.35)$ & $(0.64)$ & $(0.81)$ & $(0.23)$ & $(0.87)$ & $(0.92)$ & $(0.97)$ \\
Specification 2 & 0.28 & 1.29 & 4.78 & 1.07 & 0.035 & 0.129 & 0.118 \\
& $(0.60)$ & $(0.28)$ & $(0.91)$ & $(0.30)$ & $(0.85)$ & $(0.94)$ & $(0.99)$ \\
Specification 3 & 0.54 & 1.05 & 4.87 & 1.27 & 0.018 & 0.065 & 0.057 \\
& $(0.46)$ & $(0.37)$ & $(0.90)$ & $(0.26)$ & $(0.89)$ & $(0.97)$ & $(0.99)$ \\
\hline
\end{tabular}

p-values in parentheses.

Null hypothesis for the Breusch-Pagan/Cook-Weisberg test for heteroskedasticity is constant variance.

Null hypothesis for the Ramsey RESET test is the absence of omitted variables.

Null hypothesis for skewness and kurtosis tests is that the distribution of residuals has skewness and kurtosis corresponding to those of a normal distribution.

Null hypothesis for autoregressive conditional heteroskedasticity $(\mathrm{ARCH})$ tests is the absence of autocorrelation. 